UDC 577.218; 616.006.6

\title{
Aberrant expression of metallothioneins in clear cell renal cell carcinomas
}

\author{
V. I. Rymar ${ }^{1}$, L. V. Lototskaya ${ }^{1}$, O. G. Kondratov ${ }^{1}$, E. O. Stakhovsky², \\ O. A. Kononenko ${ }^{2}$, V. I. Kashuba ${ }^{1}$ \\ ${ }^{1}$ Institute of Molecular Biology and Genetics, NAS of Ukraine, \\ 150, Akademika Zabolotnoho Str., Kyiv, Ukraine, 03680 \\ ${ }^{2}$ National Cancer Institute, NAMS of Ukraine, \\ 33/43, Lomonosova Str., Kyiv, Ukraine, 03022 \\ rymarvi@gmail.com
}

\begin{abstract}
Aim. To find candidate tumor suppressor genes among metallothioneins for clear cell renal cell carcinoma. Methods. Analysis of the microarray data, quantitative PCR. Results. We found three genes encoding metallothioneines that showed reduced expression in different types of renal tumors, using protocol of the crossplatform meta-analysis of microarray data with normalization on several reference genes. Decreased expression of the $M T 1 G, M T 1 F$, and $M T 1 H$ genes in clear cell renal cell carcinoma was confirmed by qPCR. Conclusions. The $M T 1 G, M T 1 F$ and $M T 1 H$ genes as well as may be considered as the candidate tumor suppressor genes for ccRCC.
\end{abstract}

Ke y w or d s: metallothionein, renal tumors, candidate tumor suppressor gene, microarrays.

\section{Introduction}

Nowadays cancer is one of the major causes of death. Tumorigenesis is a result of disturbance of genome function under the influence of various factors. One of the reasons of appearance origin of the malignant cells is inactivation of the tumor suppressor genes by methylation, mutations or deletions. Metallothioneins are the small proteins, consisting of 61-68 amino acid residues and characterized by a high content of cysteine and complete absence of aromatic amino acids [1]. The genes of a metallothionein family are located on the 16q13 locus and this family consists of 10 functional isoforms [2]. There are four major genes among them: $M T 1$ (seven functional genes $M T 1 A,-1 B,-1 E,-1 F,-1 G,-1 H,-1 X), M T 2 A, M T 3$, and MT4. [The] MT1 and MT2A genes are expressed in different cell types; MT3 is expressed only in the brain and sexual organs, and MT4 only in stratified squamous epithelium in skin and tongue. Earlier it has been shown that only the $M T 1$ and $M T 2 A$ genes are involved in the regulation of embryogenesis as well as in other processes, such as interaction with metals, oxidative stress, signaling of cytokine and glucocorticoid hormones [3]. The function and expression of the $M T$ family genes in human tumors were investigated thoroughly, however, the published results are often controversial for different types of tumors; so, the real contribution of these important molecules to the malignant cell transformation has not been elucidated yet. Overexpression of the MT family genes was reported for some tumors, such as melanoma, breast and lung cancers. In contrast, expression of MT family genes is decreased upon cancerogenesis in other types of tumors, such as colon and hepatocellular carcinomas [3]. The regulation of expression of the MT family genes occurs through methylation of the promoter region. The inactivation by methylation for the $M T 1 H$ gene was demonstrated for the malignant tumors of prostate and liver [4]; for

(C) 2015 V. I. Rymar et al.; Published by the Institute of Molecular Biology and Genetics, NAS of Ukraine on behalf of Biopolymers and Cell. This is an Open Access article distributed under the terms of the Creative Commons Attribution License (http://creativecommons.org/licenses/by/4.0/), which permits unrestricted reuse, distribution, and reproduction in any medium, provided the original work is properly cited 
the $M T 1 G$ gene - in hepatoblastoma [5], thyroid tumors of different histological types [3], and in the patients with squamous cell cancer of the esophagus [6] as well. The methylation of promotor region of the $M T 1 G$ gene also was shown, especially for primary renal cell carcinoma; however, the expression has not been studied, [7]. It was demonstrated that the $M T 1 F$ expression was lower in the colon tumors due to the loss of heterozygosity $[8,9]$. Notably, the level of $M T 1 F$ gene expression in primary renal cell carcinoma remained unchanged [10].

Using the protocol of the cross-platform metaanalysis of microarray data with normalization on several reference genes, we found three isoforms of the MTl gene, the expression of which is reduced in various types of the renal tumors. Expression of the $M T 1 G, M T 1 F$, and $M T 1 H$ genes in clear cell renal cell carcinomas (ccRCC) was examined by qPCR. Our data suggest that the $M T 1 G, M T 1 F$, and $M T 1 H$ genes may act as oncosuppressors in ccRCC.

\section{Materials and Methods}

\section{Analysis of microarray and search [for] MT genes with low expression}

We performed the online search for Series and DataSet files, using http:/www.ncbi.nlm.nih.gov/geo and the following keywords: clear cell renal cell carcinoma, normal human kidney, chromophil renal cell carcinoma, chromophobe renal cell carcinoma, and oncocytoma. Series and DataSet files contain records of the data sets, which were studied by the common platform. The platform is a description of the microchip. Record describes the type of tissue, the conditions under which a single sample has been processed, manipulated incurred, and measurement results for that sample. The series [file] brings together a group of similar samples and provides description of the study. Files "Series" are provided by the authors of the study and GEO personnel transform them into a DataSet (GDSxxx). DataSet files contain information on expression levels obtained experimentally on the microchip. Each DataSet file contains the available data for a set of samples, and it is possible to compare them biologically and statistically within a single file. Files Series contain metadata translated into a format similar to the files DataSet, using package GEOquery for R (http://bioconductor.org/packages $/ 1.8 / \mathrm{bioc} / \mathrm{html} /$ GEOquery.html). Due to the fact that individual DataSet files were created by different authors, using different microarrays and equipment, it is impossible to compare the data from different files without normalization. To compare different files we have used two reference genes for normalization. For this, the expression value for each sample was divided by the geometric mean value of the PPIA and TBP expression in the same sample [11]. Upon the analysis, the average value for expression of each gene was calculated, using scripts written in Perl, for tumors and normal tissue.

\section{Total RNA isolation}

20 pairs of tumor samples and normal adjacent tissues were obtained from the National Cancer Institute of the National Academy of Medical Sciences. All tissue samples were diagnosed as the same histological type - ccRCC, which was classified, according to the American Joint Committee on Cancer (TNM) and nuclear atypia by Furman (Table 1). Total RNA was isolated, using RNeasy mini Kit (Qiagen, Valencia, $\mathrm{CA}$ ), according to the manufacturer instruction. The quality of the isolated RNA was assessed by electrophoresis, using $1 \%$ agarose gels.

\section{cDNA Synthesis}

$1 \mu \mathrm{g}$ of the total RNA was treated with the DNA-se for $30 \mathrm{~min}$ at $37^{\circ} \mathrm{C}$, and the reaction was inhibited with 25 mM EDTA (Thermo Scientific, USA). CDNA synthesis was performed, using the Oligo (dT) - primers (a final volume of reaction was $20 \mu \mathrm{l}$ ), and the First Strand cDNA Synthesis Kit (Thermo Scientific, USA), according to the manufacturer protocols.

\section{Quantitative PCR}

The real time PCR (qPCR) reactions were carried [out], using a mixture that contained $1 \mathrm{x}$ reaction mix SYBR Green (Thermo Scientific, USA), including polymerase, dNTPs, $0.4 \mu \mathrm{M}$ of each primer and 
500 ng of cDNA. [The] Reaction conditions were as follows: $95^{\circ} \mathrm{C}-10 \mathrm{~min}, 40$ cycles $95^{\circ} \mathrm{C}-15 \mathrm{~s}$, $60^{\circ} \mathrm{C}-20 \mathrm{~s}, 72^{\circ} \mathrm{C}-30 \mathrm{~s}$. A reaction volume was $25 \mu 1$. CFX96 BioRad machine was used. The quality of the PCR product was checked by the analysis of melting curves. Reactions for different samples were normalized, using the amplification reference gene TBP (encoding TATA box binding protein), which shows the constant expression in different samples. The relative fold change was calculated, using the $\Delta \Delta \mathrm{Ct}$ method. The efficiency of amplification was calculated by the R-package software, version 2.12.1 [12]. The primers were selected, using OligoAnalyzer 3.1 software. For [the] MT1G amplification the following primers were used: direct (5'GCTCCTGTGCCGCTGGTGT -3 'and reverse (5'GCAGCAGCTGCACTTCTCCGAT -3'), product size was $167 \mathrm{bp}$. For [the] $M T 1 H$ amplification - direct (5' - CCAACTGCTCCTGCGAGGCTG -3 'and

\section{Table 1.}

\begin{tabular}{|r|l|c|}
\hline \multicolumn{1}{|c|}{ N } & TNM & Stage \\
\hline 1 & T1bNxM0 & I \\
2 & T1bNxM0 & I \\
3 & T1aNxM0 & I \\
4 & T2aNxM0 & II \\
5 & T1aNxM0 & I \\
6 & T1aNxM0 & I \\
7 & T4NxMo & IV \\
8 & T1bNxMo & I \\
9 & T3NxMo & III \\
10 & T1aNxMo & I \\
11 & T1aNxMo & I \\
12 & T2aNxMo & II \\
13 & T1aNxMo & I \\
14 & T1aNxMo & I \\
15 & T2aNxMo & II \\
16 & T1bNxM0 & I \\
17 & T1aNxM0 & I \\
18 & T1bNxM0 & I \\
19 & T1aNxMo & I \\
20 & T2aNxM1 & II \\
\hline
\end{tabular}

reverse (5'- GCCCAGGGGGCAACAGGAG -3 '), product size $113 \mathrm{bp}$. For [the] MT1F amplification direct (5'- CTCCTGCACCTGCGCTGGT -3' and reverse (5'- TCTGACGCCCCTTTGCAAACA $\left.-3^{\prime}\right)$, the size of the product $-132 \mathrm{bp}$.

\section{Statistical analysis}

A comparison between the groups was done by using the independent samples $t$ test. A value of $\mathrm{P}<0.05$ was considered as statistically significant.

\section{Results and Discussion}

7 files that contain the data of gene expression in tumors and normal kidney tissue were found in the GEO database. In total, there were $9 \mathrm{ccRCC}$ of stage 1 by Furman, 11 ccRCC of stage 2, 14 ccRCC samples of stage 3 as well as 55 chromophyle and 14 chromophobe kidney tumors, 14 oncocytomas, and 23 samples of normal tissue. The genes were selected that showed a decrease in the expression by more than 5 fold $(\mathrm{P}<0.05)$, compared with the normal tissue. Then the search for the MT family genes was performed, looking for the genes with reduced expression in all six tumor types. Three such genes $M T 1 G, M T 1 H$, and $M T 1 F$ - were found. There are the literature data showing changes in their expression during the development of various cancers, that is why we assumed that these genes might be suppressors for kidney tumors. For each patient, the tumor and normal tissue samples were paired. The normal tissue control samples were represented by the adjacent to the tumor but not malignantly transformed kidney tissues. To study the gene expression pattern, 20 pairs of samples (tumor/norma) from the renal carcinomas of varying degrees of malignancy were used (Table 1).

\section{$M T 1 G$, metallothionein $1 G$}

The MT1G expression decreased significantly $(\mathrm{P}=0.0047)$ in ccRCC samples, compared with normal tissue (Fig. 1), that is in line with the results for other types of tumors [3,10, 13-15]. The main mechanism of the regulation of $M T 1 G$ gene expression is associated with promoter hyper-methylation. Hyper- 


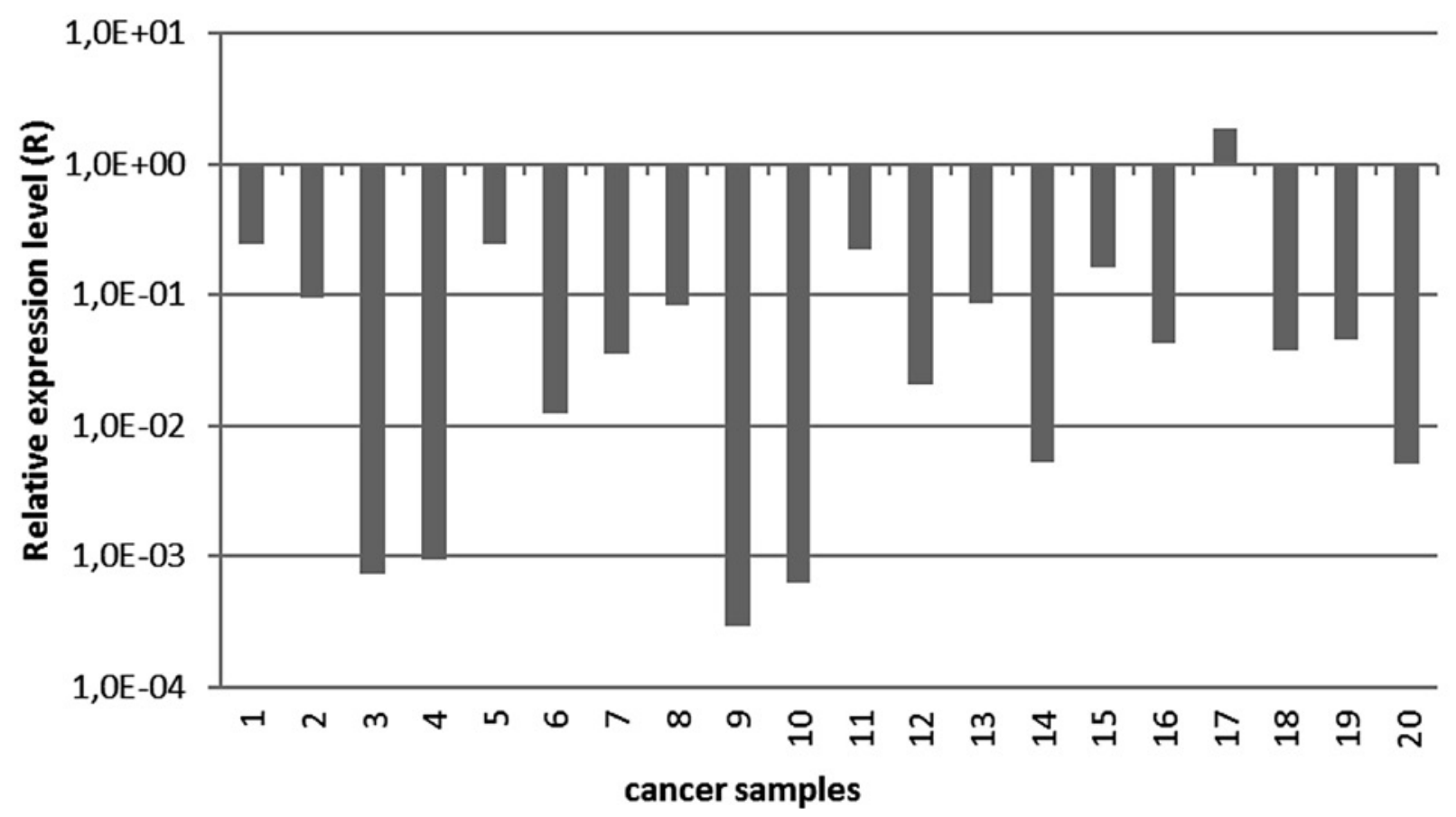

Fig. 1. Relative mRNA level of $M T 1 G$ gene in ccRCC compared to normal tissue, assessed by qPCR.

methylation of promoter region of the $M T 1 G$ was observed in hepatoblastoma, hepatocellular carcinoma, thyroid tumors of different histological types, esophageal squamous cell cancer and prostate tumors $[3,5$, $6,13,16]$. The rate of hyper-methylation of $M T 1 G$ promoter showed correlation with poor prognosis for patients with hepatoblastomas. So, hyper-methylation of the $M T 1 G$ promoter might be useful as a prognostic factor for the course of disease; moreover, demethylation of this gene in hepatoblastoma might suggest the positive effect in the treatment [5]. The level of $M T 1 G$ promoter methylation in prostate tumors correlates with tumor progression stage, but not with stage by Gleason. The MTIG promoter hypermethylation was observed more frequently in prostate tumors that spread beyond the prostate capsule. So, the $M T 1 G$ promoter methylation is associated with the aggressive prostate cancer [16].

The qPCR results showed that the $M T 1 G$ gene expression also reduced in ccRCC compared with normal tissue. Thus, the $M T 1 G$ gene may be a potential tumor suppressor for ccRCC. Moreover, it might be also used as a prognostic tumor marker.

\section{MT1F, metallothionein $1 F$}

Expression of the $M T 1 F$ gene was significantly lower $(\mathrm{P}=0.00077)$ in ccRCC compared with normal tissue (Fig. 2). Only in tumor number 17, there was a slight increase in the expression.

Earlier a significant reduction of the $M T 1 F$ gene expression has been demonstrated only for colon tumors and hepatocellular carcinomas [8, 17]. Overexpression of MTIF in the RKO colon cancer cell line resulted in promotion of apoptosis and also prevented cell migration, invasion and adhesion in vitro. A reduced expression of the MT1F gene in colon tumors was observed, due to loss of heterozygosity ( $p$ $=0.001$ ), whereas the methylation of $\mathrm{CpG}$ islands in the promoter region of the $M T 1 F$ gene was observed only in colon cancer cell lines RKO and LoVo. So, $M T 1 F$ is a potential tumor suppressor of colon cancers, which inhibited mainly, due to loss of heterozygosity [8]. When the HepG2 cell line was transfected with [an] expression vector pCMV-MT1F, the cells proliferated slowlier, compared with the control line HepG2. It was also reported that the $M T 1 F$ expression at the mRNA and protein levels is significantly higher 


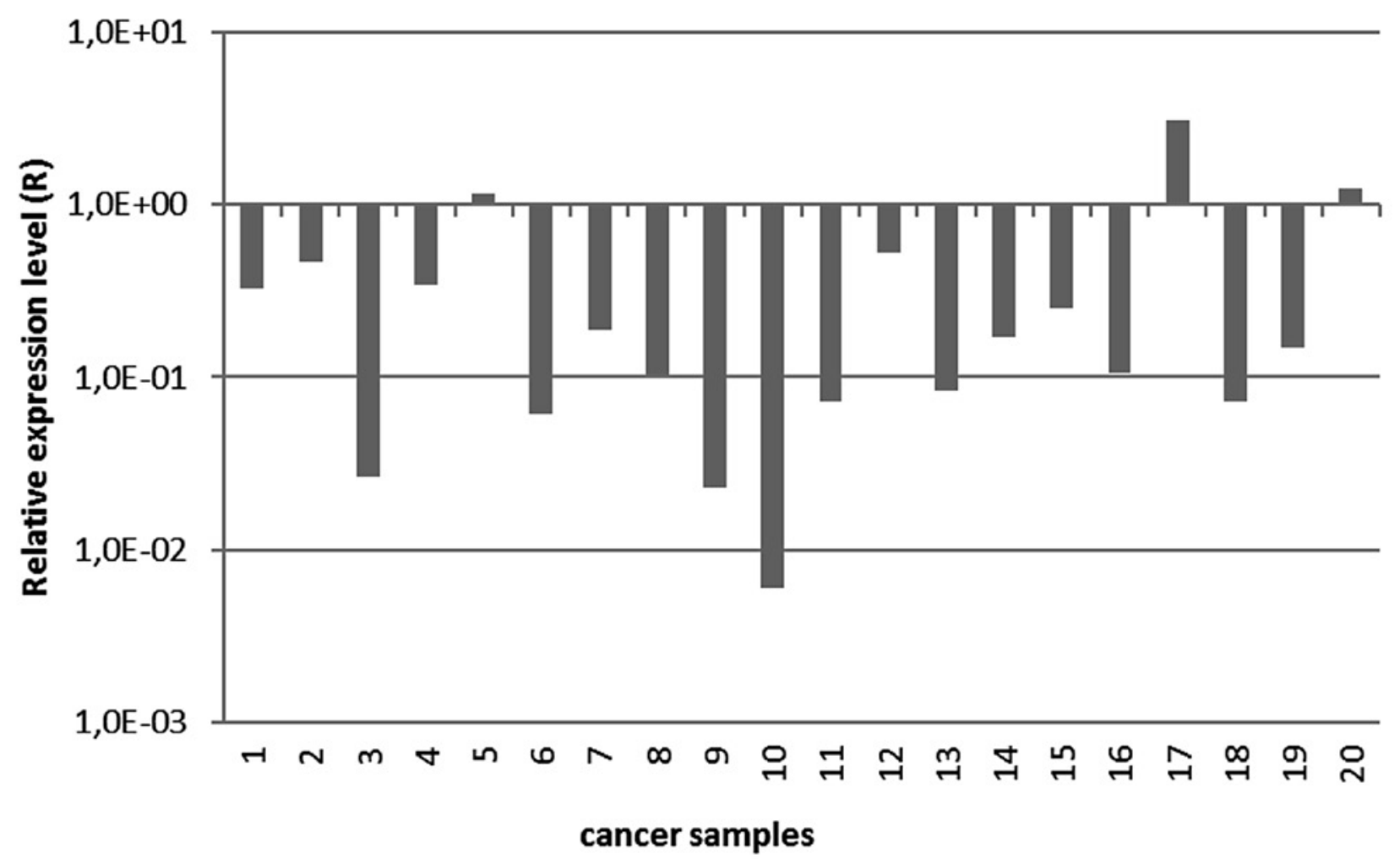

Fig. 2. Relative mRNA level of $M T I F$ gene in ccRCC compared to normal tissue, assessed by qPCR.

in the normal tissue, than in hepatocellular carcinomas. Hence, MTIF may play an important role in gene therapy of hepatocellular carcinoma [17]. Earlier it has been shown that the MTIF expression levels in primary renal cell carcinoma remain unchanged in comparison with the control group [10].

According to the obtained data (microarray analysis with GEO and qPCR), expression of the MT1F gene significantly reduced in ccRCC. As the MT1F gene is the potential suppressor for colon tumors and hepatocellular carcinomas, and therewith it showed reduced expression in tumors of the kidneys, we suppose that the MT1F gene is the putative tumor suppressor for ccRCC and might be used as the tumor progression marker.

\section{MT1H, metallothionein $1 H$}

Expression of the $M T 1 H$ gene significantly $(\mathrm{P}=$ $0.004)$ reduced in ccRCC compared with normal tissue (Fig. 3).
The main mechanism of the gene expression regulation is associated with the $M T 1 H$ promoter hypermethylation. So, inter-connection between the promoter methylation and the gene $M T 1 H$ expression was shown in prostate and liver tumors. The low $M T 1 H$ expression was also associated with poor clinical outcomes for patients with both, prostate and liver cancers. De-methylation of promoter in cell lines in vitro restores the $M T 1 H$ gene expression, leading to a slower cell proliferation, suppression of colony formation, and reduced ability of cells to migrate [4]. It was shown that MT1H can interact with euchromatin histone methyltransferase 1 (EHMT1) enhancing its methyltransferase activity on histone 3. Inhibition of the interaction between EHMT1 and MT1H leads to inactivation of the tumor suppression by $M T 1 H$ [4]. As has been shown earlier, the primary renal cell carcinoma biopsy specimens had a lower expression of the $M T 1 H$ transcripts than the pooled normal human controls [10]. 


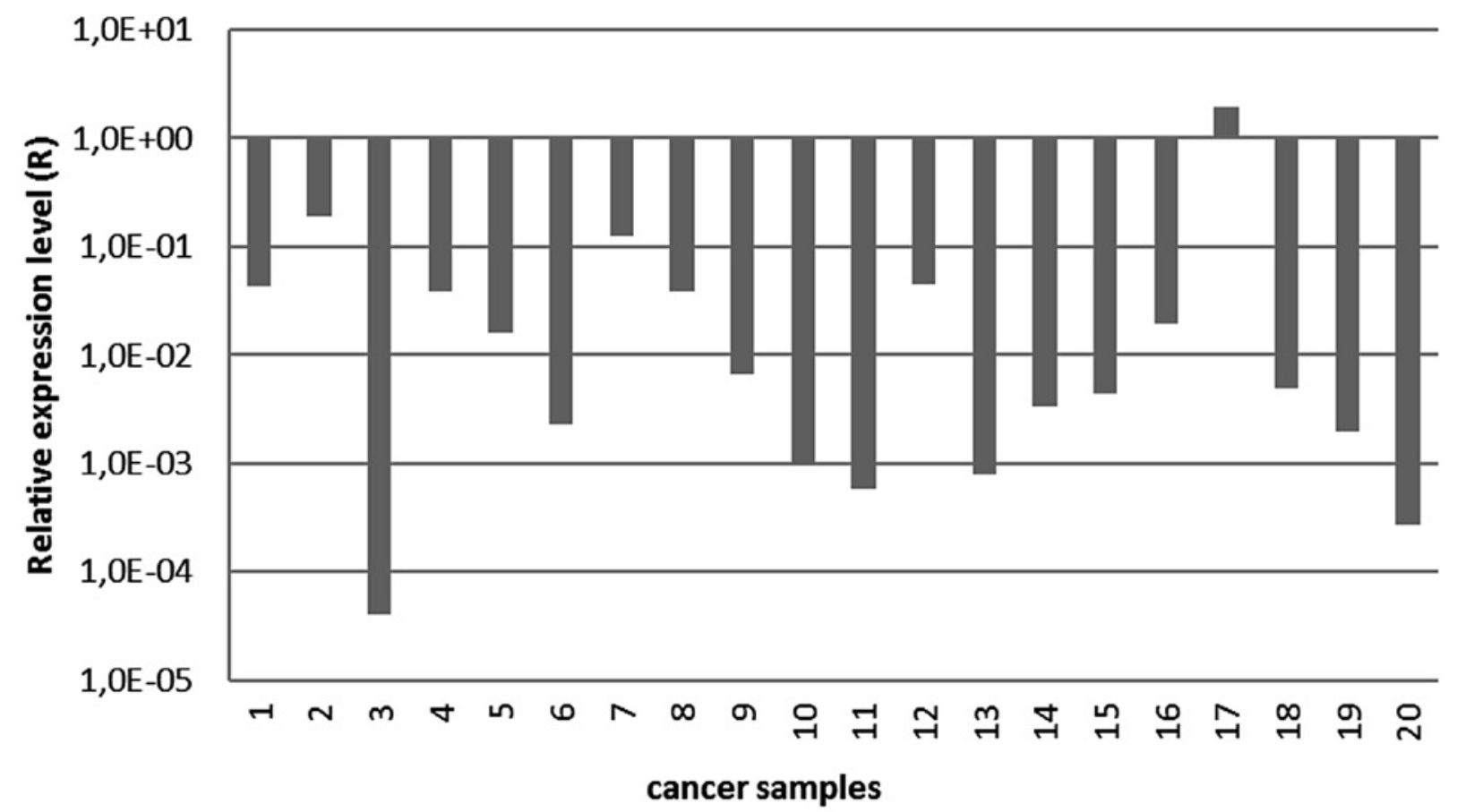

Fig. 3. Relative expression of the $M T 1 H$ gene at the mRNA level, assessed by qPCR in ccRCC compared with normal tissue.

Our qPCR data of the $M T 1 H$ gene expression in ccRCC type in comparison with normal tissue show the same trend. Since the $M T 1 H$ functions as the growth suppressor for prostate and liver tumors, and therewith shows a lower expression in the primary renal cell carcinoma, we suppose that this gene is the tumor growth suppressor for ccRCC. The MTIH gene might be used also as a tumor marker.

\section{Conclusions}

Using the protocol of the cross-platform meta-analysis of microarray data with normalization on several reference genes we have found three genes of the $M T$ family that showed reduced expression in different types of renal tumors. The expression of the $M T 1 G, M T 1 F$, and $M T 1 H$ genes in ccRCC was also studied by qPCR. Taking into consideration that the $M T 1 G$ gene is a potential suppressor for different types of tumors, the $M T I F$ gene is a potential suppressor for colon tumors and hepatocellular carcinoma, and the $M T I H$ gene is a potential suppressor for prostate and liver cancers, we suppose that these genes are potential suppressors for ccRCC and can be used as the tumor markers.

\section{REFERENCES}

1. Tai SK, Tan OJ, Chow VT, Jin R, Jones JL, Tan PH, Jayasurya A, Bay BH. Differential expression of metallothionein 1 and 2 isoforms in breast cancer lines with different invasive potential: identification of a novel nonsilent metallothionein1H mutant variant. Am J Pathol. 2003;163(5):2009-19.

2. Vandeghinste N, Proost P, De Ley M. Metallothionein isoform gene expression in zinc-treated human peripheral blood lymphocytes. Cell Mol Biol (Noisy-le-grand). 2000;46(2):419-33.

3. Ferrario C, Lavagni P, Gariboldi M, Miranda C, Losa M, Cleris L, Formelli F, Pilotti S, Pierotti MA, Greco A. Metallothionein $1 \mathrm{G}$ acts as an oncosupressor in papillary thyroid carcinoma. Lab Invest. 2008;88(5):474-81.

4. Han YC, Zheng ZL, Zuo ZH, Yu YP, Chen R, Tseng GC, Nelson JB, Luo JH. Metallothionein 1 h tumour suppressor activity in prostate cancer is mediated by euchromatin methyltransferase 1. J Pathol. 2013;230(2):184-93.

5. Sakamoto LH, DE Camargo B, Cajaiba M, Soares FA, Vettore $A L$. MT1G hypermethylation: a potential prognostic marker for hepatoblastoma. Pediatr Res. 2010;67(4):387-93.

6. Roth MJ, Abnet CC, Hu N, Wang QH, Wei WQ, Green L, D'Alelio M, Qiao YL, Dawsey SM, Taylor PR, Woodson K. 
p16, MGMT, RARbeta2, CLDN3, CRBP and MT1G gene methylation in esophageal squamous cell carcinoma and its precursor lesions. Oncol Rep. 2006;15(6):1591-7.

7. Morris MR, Hesson LB, Wagner KJ, Morgan NV, Astuti D, Lees RD, Cooper WN, Lee J, Gentle D, Macdonald F, Kishida T, Grundy R, Yao M, LatifF, Maher ER. Multigene methylation analysis of Wilms' tumour and adult renal cell carcinoma. Oncogene. 2003;22(43):6794-801.

8. Yan DW, Fan JW, Yu ZH, Li MX, Wen YG, Li DW, Zhou CZ, Wang XL, Wang $Q$, Tang HM, Peng ZH. Downregulation of metallothionein $1 \mathrm{~F}$, a putative oncosuppressor, by loss of heterozygosity in colon cancer tissue. Biochim Biophys Acta. 2012;1822(6):918-26.

9. Nagai H, Ponglikitmongkol M, Fujimoto J, Yamamoto H, Kim YS, Konishi N, Matsubara K. Genomic aberrations in early stage human hepatocellular carcinomas. Cancer. 1998;82(3):454-61.

10. Nguyen A, Jing Z, Mahoney PS, Davis R, Sikka SC, Agrawal $K C$, Abdel-Mageed $A B$. In vivo gene expression profile analysis of metallothionein in renal cell carcinoma. Cancer Lett. 2000;160(2):133-40.

11. Vandesompele J, De Preter K, Pattyn F, Poppe B, Van Roy $N$, De Paepe A, Speleman F. Accurate normalization of realtime quantitative RT-PCR data by geometric averaging of multiple internal control genes. Genome Biol. 2002;3(7):RESEARCH0034.

12. Spiess AN, Feig C, Ritz C. Highly accurate sigmoidal fitting of real-time PCR data by introducing a parameter for asymmetry. BMC Bioinformatics. 2008;9:221.

13. Kanda M, Nomoto S, Okamura Y, Nishikawa Y, Sugimoto H, Kanazumi N, Takeda S, Nakao A. Detection of metallothionein $1 \mathrm{G}$ as a methylated tumor suppressor gene in human hepatocellular carcinoma using a novel method of double combination array analysis. Int J Oncol. 2009;35(3):477-83.

14. Morris MR, Gentle D, Abdulrahman M, Clarke N, Brown $M$, Kishida T, Yao M, Teh BT, Latif F, Maher ER. Functional epigenomics approach to identify methylated candidate tumour suppressor genes in renal cell carcinoma. Br J Cancer. 2008;98(2):496-501.

15. Arriaga JM, Levy EM, Bravo AI, Bayo SM, Amat M, Aris M, Hannois A, Bruno L, Roberti MP, Loria FS, Pairola A, Huertas E, Mordoh J, Bianchini M. Metallothionein expression in colorectal cancer: relevance of different isoforms for tumor progression and patient survival. Hum Pathol. 2012;43(2):197-208.

16. Henrique R, Jerónimo C, Hoque MO, Nomoto S, Carvalho AL, Costa VL, Oliveira J, Teixeira MR, Lopes C, Sidransky $D$. MT1G hypermethylation is associated with higher tumor stage in prostate cancer. Cancer Epidemiol Biomarkers Prev. 2005;14(5):1274-8.

17. $L u D D$, Chen YC, Zhang XR, Cao XR, Jiang $H Y$, Yao L. The relationship between metallothionein-1F (MT1F) gene and hepatocellular carcinoma. Yale J Biol Med. 2003;76(2):55-62.

\section{Зміна рівня експресії металотіонеїнів при світло- клітинній карциномі нирок}

В. І. Римар, Л. В. Лотоцкая, О. Г. Кондратов, Е. О. Стаховський, О. А. Кононенко, В. І. Кашуба

Мета. Пошук потенційних генів-супресорів серед металотіонеїнів при розвитку світло-клітинної карциноми нирок. Методи. Біоінформатичний аналіз баз даних мікрочіпів, кількісна ПЛР. Результати. Використовуючи біоінформатичні методи порівняння різних баз даних мікрочипів із застосуванням кросплатформенної нормалізації по декількох референтних генах, нами було знайдено три гени з родини металотіонеїнів, що показують знижену експресію у різних типах пухлин нирок. Зниження експресії генів $M T 1 G, M T l F$ та $M T 1 H$ в зразках світлоклітинної карциноми нирок було продемонстровано методом кількісної ПЛР. Висновки. Гени $M T 1 G, M T 1 F$ та $M T 1 H$ $€$ потенційними супресорами росту пухлин нирок.

Кл юч о в і с л о в а: металотіонеїни, пухлини нирок, потенційний ген-супресор росту пухлин, мікрочіпи

\section{Изменение уровня экспрессии генов металлотионеинов при светло-клеточной карциноме почек}

В. И. Рымар, Л. В. Лотоцкая, А. Г. Кондратов, Э. А. Стаховский, А. А. Кононенко, В. И. Кашуба

Цель. Поиск потенциальных генов-супрессоров светло-клеточной карциномы почек среди металлотионеинов. Методы. Анализ результатов микрочипов, выделение тотальной РНК, количественная ПЦР. Результаты. Используя метод сравнения результатов микрочипов с применением кроссплатформенной нормализации по нескольким референтным генам, нами были найдены три гена семейства металлотионеинов с пониженной экспрессией в различных типах опухолей почек. Снижение экспрессии генов $M T 1 G, M T 1 F$ и $M T 1 H$ в светлоклеточной карциноме почек было продемонстрировано методом количественной ПЦР. Выводы. Гены $M T 1 G, M T 1 F$ и $M T 1 H$ могут рассматриваться как потенциальные супрессоры роста опухолей почек.

Кл юч ев ы с л о в: металлотионеин, опухоли почек, потенциальный ген-супрессор. 